American Journal of Animal and Veterinary Sciences 6 (1): 40-44, 2011

ISSN 1557-4555

(C) 2011 Science Publications

\title{
Effects of Dietary Supplementation with Pumpkin oil (Cucurbita pepo) on Performance and Blood Fat of Broiler Chickens during Finisher Period
}

\author{
${ }^{1}$ Hosna Hajati, ${ }^{1}$ Ahmad Hasanabadi and ${ }^{2}$ Park W.Waldroup \\ ${ }^{1}$ Department of Animal Science, Excellence Center of Animal Research \\ Ferdowsi University of Mashhad, Mashhad, P. O. Box: 91775-1163, Iran \\ ${ }^{2}$ Department of Poultry Science, University of Arkansas, \\ Fayetteville, Arkansas 72701, USA
}

\begin{abstract}
Problem statement: Using most of antibiotic growth promoters as feed additives has been banned by the European Union due to cross-resistance against pathogens and residues in tissues; and scientists search for alternatives to antibiotics, two days. In this view, medicinal plants and essential oils extracted are becoming more important due to their antimicrobial and stimulating effects on animal digestive systems. Approach: This study was conducted to evaluate the use of Pumpkin oil in broiler nutrition as a natural growth promoting substance and its effect on abdominal and blood fat. A total of 144 one-day-old broiler chicks (Ross 308) were used in a completely randomized design with 3 treatments and 3 replicates. The experiment was conducted from 29-49 d of age. The main ingredients of diets included corn, soybean meal and wheat. The pumpkin oil levels added to the diets were 0.00 (control), 5.00 and $10.00 \mathrm{~g} \mathrm{~kg}^{-1}$ DM. Results: Pumpkin oil supplementation up to $5.00 \mathrm{~g} \mathrm{~kg}^{-1} \mathrm{DM}$ diet had not significant effect on broilers performance, but supplementation in higher level $\left(10.00 \mathrm{~g} \mathrm{~kg}^{-1} \mathrm{DM}\right)$ significantly decreased broilers performance. Pumpkin oil supplementation decreased bird's mortality. Adding pumpkin oil had not any significant effect on abdominal fat pad and carcass composition, however cholesterol and triglyceride concentrations in plasma decreased at 49 days of age $(\mathrm{P}<0.05)$. Conclusion: Results of this study indicated that supplementation of diets with $5.00 \mathrm{~g} \mathrm{~kg}^{-1} \mathrm{DM}$ pumpkin oil in corn-soybean meal-wheat based diet can be profitable because it reduced broiler chicken's mortality and it did not have any adverse effect on bird's performance.
\end{abstract}

Key words:Pumpkin oil, carcass composition, abdominal fat pad, blood fat, corn-soybean meal-wheat, animal digestive systems, antimicrobial, antiinflamatory, carcass composition, phytochemical, dietary protein

\section{INTRODUCTION}

After the use of most antibiotic growth promoters as feed additives has been banned by the European Union due to cross-resistance against pathogens and residues in tissues, scientists have searched for alternatives to antibiotics. In this view, aromatic plants and essential oils extracted from these plants are becoming more important due to their antimicrobial effects and the stimulating effect on animal digestive systems (Ciftci et al., 2005). Beneficial effects of botanical additives in farm animal may arise from activation on feed intake and digestive secretions, immune stimulation, antibacterial, coccidiostatical, antihelmintical, antiviral or antiinflamatory activity. In plant tissues, $\mathrm{pH}$ values are dependent on the presence of poly-carboxylic acids, phosphate salts, fiber and proteins (Al-Dabbas et al., 2010). Even two plants have the same total chemical composition, if inherent structures different, the nutritive values are different. For example, Harrington barley and Valier barley which are similar in chemical composition, but digestive behavior and nutrient availability are completely different (Yu, 2007). Nowadays, Wheat Germ Agglutinin (WGA), Peanut Agglutinin (PNA) and Concavilin (Cona) are being used widely for studying sugar compounds on the surface of cells (Yazdani Moghaddam et al., 2009). The use of maize oil in diet of grouper resulted in substantial growth and excellent feed efficiency. Grouper seem able to efficiently utilize maize oil as the dietary lipid source as long as their requirement for essential fatty acids are

Corresponding Author: Hosna Hajati, Department of Animal Science, Excellence Center of Animal Research Ferdowsi, University of Mashhad, Mashhad, Iran 
met (Niu et al., 2007). A larger number of plants and their isolated constituents have been shown to modulate immunity. Some medicinal plants have been shown to exert anti-inflammatory, anti-stress and anti-cancer effects by modulating the immune functions (Salem et al., 2005). Cyperus Medicinal plants have become part of complementary medicine worldwide, because of their potential health benefits. Plants have been used for centuries in the medical practices mostly in therapy of diverse pathologies. Nopal is widely used in Mexico as a treatment for glucose control and is known in the United States as prickly pear cactus. $\mathrm{N}$. cochenillifera pads are rich in vitamin A and have been used for headaches, eye troubles and insomnia if consumed as a tea. In addition, the split pads are emollient and used as poultices on rheumatism and baked for ulcers, gout and wounds. This plant is good for warts, kidney problems, measles and as a vermifuge for gastro-intestinal parasites, used sparingly (Gomez-Flores et al., 2006).

C. pepo is a member of the family of Curcubitaceae which also includes C. maxima, C. mixta and C. moschata. C. pepo (flutted pumpkin) is ovoid in shape with a curved green shell. Inside the shell is a flat, round, yellow and white seed enclosed in a husk. These seeds are chewable and sweet with a nutty flavor. Besides having important edible uses and another as an industrial food additive, C. pepo also has medicinal uses including antihelminthic as well as natural laxative. In addition it has been widely applied in the treatment of benign prostatic hyperplasia in men, obesity, skin problems and irritable bladder (enuresis) in children (Obi et al., 2009).

Pumpkin contributes to nutrition though an abundant supply of minerals, vitamin and especially bcarotene (Gwanama et al., 2001). Many Plants contain extensive variety of phytochemical compounds with antimicrobial activity (Cowan, 1999). Plant extracts have demonstrated to have an antimicrobial effect in vitro, but their influence on growth of farm animal species has not been demonstrated yet. Researchers have examined various herbs that possess hypolipidemic, antiplatelet, antitumor, or immunestimulating properties that may be useful adjuncts in helping reduce the risk of cardiovascular disease and cancer. In addition to their antimicrobial activity (Valero and Salmeron, 2003), they posses biological activities such as that of antioxidants (Botsoglou et al., 2002) and as hypocholesterolemics (Craig, 1999) and stimulate effect on animal digestive systems (Jamroz and Kamel, 2002; Ramakrishna et al., 2003), to increase production of digestive enzymes and improve utilization of digestive products through enhanced liver functions (Hernandez et al., 2004). In limited research, some aromatic plants and their components on the performance, the addition of these substances to the feeds and water improved feed intake, feed conversion ratio and carcass yield (Alçiçek et al., 2003). In contrast to plants, animals contain a greater percentage of protein because of their lower water content, a fact which allows humans to consume a smaller quantity for the same food value. In addition to supplying the highest quality of protein, animal foods are rich sources of the B vitamins whereas some plant foods are deficient in these factors. Because the body's need for protein is related to its rate of growth, the need for protein is much greater in infants than in older children or adults. There seems to be little disagreement among scientists that protein malnutrition contributes to the high death rate among infants and children of the less developed countries and causes among the survivors debilitating weakness, higher susceptibility to disease and irreversible brain damage (Ghaly, 2009). So researchers must pay attention to the protein quality of foods such as broilers meat.

Therefore, the objectives of this study were to examine the effects of Pumpkin oil (Cucurbita pepo) on performance, abdominal fat pad, carcass composition and blood fat in broiler chickens.

\section{MATERIALS AND METHODS}

A total of 144, one-day old mixed-sex broiler chicks (Ross 308) were obtained from a commercial hatchery on the hatching day. The experimental design was CRD with 3 treatments and 4 replicates with 12 chicks in each replicate. Treatments included 3 levels of a pumpkin oil $\left(0.00,5.00\right.$ and $10.00 \mathrm{~g} \mathrm{~kg}^{-1} \mathrm{DM}$, Barij esans Inc., Iran). The metabolizable energy content of Pumpkin oil was about $8105 \mathrm{Kcal} / \mathrm{Kg}$ with $5.62 \%$ moisture and 23.75 peroxide number. The experiment conducted during finisher period (29-49 days) of broilers life. The room was lit continuously during the whole experimental period and room temperature was controlled at $26^{\circ} \mathrm{C}$ and then gradually reduced by $2-3^{\circ} \mathrm{C}$ per week to a final temperature of $18^{\circ} \mathrm{C}$. All diets were formulated to meet the nutrient requirements according to Ross 308 rearing guideline. The composition and nutrient levels of the basal diet are shown in Table 1. Feed and water were provided ad libitum during the whole trial period. Daily mortalities were recorded and used to correct performance criteria. Chickens were weighed at 28 and 49 days of age. Body weight mean of birds at the start of the experiment (29 days) was 1.393 $\mathrm{Kg}$. At 49 days of age, blood sample was collected from wing vein of the birds. Blood samples were kept on ice, centrifuged and plasma stored at $-20^{\circ} \mathrm{C}$ until hormone and metabolite analyses were carried out. 
American J. Animal \& Vet. Sci., 6 (1): 40-44, 2011

The concentrations of cholesterol and triglyceride were measured using appropriate commercial laboratory kits (zistshimi and parsazmoon).

Plasma parameters were measured according to the manufacturer's instructions. At the end of the experiment (49 day) 2 birds from each pen with body weight close to the pen average body weight were selected for carcass analyses. After feed withheld for 9 $\mathrm{h}$, the selected birds were transported to the university pilot for processing. The chickens were slaughtered by cervical dislocation to determine the abdominal fat pad and carcass composition.

Supplied per kilogram of diet: About $6050 \mu \mathrm{g}$ vitamin A (retinyl acetate + retinyl palmitate), $55 \mu \mathrm{g}$ vitamin D3, $22.05 \mu \mathrm{g}$ vitamin $\mathrm{E}$ (alpha-topheryl acetate), $2.0 \mathrm{mg}$ vitamin $\mathrm{K} 3,5 \mathrm{mg}$ vitamin $\mathrm{B} 1,6.0 \mathrm{mg}$ vitamin $\mathrm{B} 2,60 \mathrm{mg}$ vitamin $\mathrm{B} 3,4 \mathrm{mg}$ vitamin $\mathrm{B} 6,0.02 \mathrm{mg}$ vitamin $\mathrm{B} 12,10.0$ $\mathrm{mg}$ pantothenic acid, $6.0 \mathrm{mg}$ folic acid, $0.15 \mathrm{mg}$ biotin, $0.625 \mathrm{mg}$ ethoxyquin; ${ }^{2}$ : Suppled per kg of diet: $500 \mathrm{mg}$ $\mathrm{CaCO}_{3}, 80 \mathrm{mg} \mathrm{Fe}, 80 \mathrm{mg} \mathrm{Zn}, 80 \mathrm{mg} \mathrm{Mn}, 10 \mathrm{mg} \mathrm{Cu}, 0.8$ mg I, $0.3 \mathrm{mg} \mathrm{Se}$.

Table 1: Composition of experimental diets in period of the experiment (29-49 days)

\begin{tabular}{|c|c|}
\hline Ingredients $(\%)$ & $\begin{array}{l}\text { Finisher } \\
\text { 29-49 days }\end{array}$ \\
\hline Corn & 39.63 \\
\hline Soybean meal & 33.61 \\
\hline Wheat & 21.04 \\
\hline Vegetable oil & 1.63 \\
\hline Dicalcium phosphate & 1.16 \\
\hline Oyster shell & 1.40 \\
\hline Common salt & 0.30 \\
\hline Mineral premix $^{1}$ & 0.25 \\
\hline Vitamin premix ${ }^{2}$ & 0.25 \\
\hline DL-methionine & 0.34 \\
\hline L-Lysine $\mathrm{HCl}$ & 0.34 \\
\hline Total & 100.00 \\
\hline \multicolumn{2}{|l|}{ Calculated analysis } \\
\hline $\operatorname{ME}\left(\mathrm{kcal} \mathrm{kg}^{-1}\right)$ & 3050.00 \\
\hline Crude protein $(\%)$ & 18.00 \\
\hline Calcium (\%) & 0.86 \\
\hline Available phosphorus (\%) & 0.43 \\
\hline Sodium (\%) & 0.14 \\
\hline Arginine $(\%)$ & 1.09 \\
\hline Lysine (\%) & 1.08 \\
\hline Methionine $(\%)$ & 0.28 \\
\hline Methionine + cysteine $(\%)$ & 0.88 \\
\hline Threonine (\%) & 0.64 \\
\hline Tryptophan (\%) & 0.21 \\
\hline \multicolumn{2}{|c|}{$\begin{array}{l}\text { ': Supplied per kilogram of diet: } 6050 \mu \mathrm{g} \text { vitamin A (retinyl acetate + } \\
\text { retinyl palmitate), } 55 \mu \mathrm{g} \text { vitamin } \mathrm{D} 3,22.05 \mu \mathrm{g} \text { vitamin } \mathrm{E} \text { (alpha- } \\
\text { topheryl acetate), } 2.0 \mathrm{mg} \text { vitamin } \mathrm{K} 3,5 \mathrm{mg} \text { vitamin } \mathrm{B} 1,6.0 \mathrm{mg} \\
\text { vitamin B2, } 60 \mathrm{mg} \text { vitamin B3, } 4 \mathrm{mg} \text { vitamin B6, } 0.02 \mathrm{mg} \text { vitamin } \\
\mathrm{B} 12,10.0 \mathrm{mg} \text { pantothenic acid, } 6.0 \mathrm{mg} \text { folic acid, } 0.15 \mathrm{mg} \text { biotin, } \\
0.625 \mathrm{mg} \text { ethoxyquin; }{ }^{2} \text { : Suppled per kg of diet: } 500 \mathrm{mg} \mathrm{CaCO}, 80 \\
\mathrm{mg} \mathrm{Fe}, 80 \mathrm{mg} \mathrm{Zn}, 80 \mathrm{mg} \mathrm{Mn}, 10 \mathrm{mg} \mathrm{Cu}, 0.8 \mathrm{mg} \mathrm{I}, 0.3 \mathrm{mg} \mathrm{Se}\end{array}$} \\
\hline
\end{tabular}

Statistical analysis: Data of this experiment were analyzed by analysis of variance using GLM procedures (SAS institute, 2001). Differences among means were compared by Duncan's multiple range test at 5\% probability (Duncan, 1955). Statistical model of this experiment was as follow:

$\mathrm{Xij}=\mu+\mathrm{Ti}+\mathrm{eij}$

where, $\mu, \mathrm{Ti}$ and eij are overall mean, the treatment and experimental error effects respectively.

\section{RESULTS}

Performance and mortality: The effects of pumpkin oil supplementation on broiler's performance are shown in Table 2. Adding pumpkin oil up to $10 \mathrm{~g} \mathrm{~kg}^{-1} \mathrm{DM}$ decreased feed intake and body weight gain $(\mathrm{p}<0.05)$, however the difference between bird's feed conversion ratio were not significant. Pumpkin oil supplementation decreased broiler chicken's mortality $(\mathrm{p}<0.05)$.

Abdominal fat pad and carcass composition: Effects of pumpkin oil supplementation on abdominal fat pad and carcass composition on 49 days age are shown in Table 3. Although using pumpkin oil in diets decreased abdominal fat pad numerically, it had not any significant effect on abdominal fat pad and carcass composition of broiler chickens.

Blood parameters: The effects of pumpkin oil supplementation on some blood fat parameters for 44 days are shown in Table 4. The results of this study showed that enzyme addition decreased the concentration of blood cholesterol and triglyceride $(\mathrm{p}<0.05)$.

Table 2: Effects of pumpkin oil on body weight gain feed intake, feed/gain and mortality in broiler chickens (29-49 d)

\begin{tabular}{lcccc}
\hline Item & $\mathrm{T}_{1}$ & \multicolumn{1}{c}{$\mathrm{T}_{2}$} & $\mathrm{~T}_{3}$ & SEM \\
\hline Weight gain (g/bird) & $2598.000^{\mathrm{a}}$ & $2580.000^{\mathrm{ab}}$ & $2568.400^{\mathrm{b}}$ & 7.930 \\
Feed intake (g/bird) & $877.750^{\mathrm{a}}$ & $869.500^{\mathrm{ab}}$ & $862.390^{\mathrm{b}}$ & 4.810 \\
Feed/gain $\left(\mathrm{g} \mathrm{g}^{-1}\right)$ & 2.963 & 2.971 & 2.978 & 0.010 \\
Mortality & $2.500^{\mathrm{a}}$ & $0.000^{\mathrm{b}}$ & $0.000^{\mathrm{b}}$ & 0.009
\end{tabular}

Means within rows with different superscripts differ significantly $(\mathrm{p}<0.05)$

Table 3: Effects of pumpkin oil on abdominal fat pad and carcass composition of broiler chickens at 49 days of age

\begin{tabular}{lcccc}
\hline Items & $\mathrm{T}_{1}$ & $\mathrm{~T}_{2}$ & $\mathrm{~T}_{3}$ & $\mathrm{SEM}$ \\
\hline $\begin{array}{l}\text { Abdominal fat pad } \\
\text { (\%Carcass weight) }\end{array}$ & 2.425 & 2.407 & 2.391 & 0.10 \\
$\begin{array}{l}\text { Carcass dry } \\
\text { matter } \% \text { DM) }\end{array}$ & 28.030 & 28.410 & 28.620 & 0.55 \\
$\begin{array}{l}\text { Carcass fat } \\
(\% \text { DM) }\end{array}$ & 40.780 & 40.690 & 40.580 & 0.51 \\
$\begin{array}{l}\text { Carcass protein } \\
(\% \mathrm{DM})\end{array}$ & 50.060 & 50.110 & 50.200 & 0.53 \\
\hline $\mathrm{p}<0.05$ & & & & \\
\hline
\end{tabular}


American J. Animal \& Vet. Sci., 6 (1): 40-44, 2011

Table 4: Effects of pumpkin oil on plasma cholesterol and triglyceride of broilers at 49 day

\begin{tabular}{lllll}
\hline Items & $\mathrm{T}_{1}$ & $\mathrm{~T}_{2}$ & $\mathrm{~T}_{3}$ & $\mathrm{SEM}$ \\
\hline $\begin{array}{l}\text { Cholesterol } \\
\left(\mathrm{mg} \mathrm{dL}^{-1}\right)\end{array}$ & $161.4^{\mathrm{a}}$ & $158.2^{\mathrm{a}}$ & $149.7^{\mathrm{b}}$ & 4.01 \\
$\begin{array}{l}\text { Triglyceride } \\
\left.(\mathrm{mg} \mathrm{dL})^{-1}\right)\end{array}$ & $49.5^{\mathrm{a}}$ & $44.7^{\mathrm{a}}$ & $38.2^{\mathrm{b}}$ & 1.37 \\
$\begin{array}{l}\text { Means within rows with different superscripts } \\
(\mathrm{p}<0.05)\end{array}$ & & & \\
\hline
\end{tabular}

\section{DISSCUSION}

Performance and mortality: The results of this study were in agreement with the findings of Lee et al. (2003). They investigated the effect of Thymol and Carvacrol on female broiler chick performance and reported that dietary carvacrol lowered feed intake and weight gain. Possibly, pumpkin oil decreased feed intake in the present study by affecting the appetite of broiler chicken. Deyoe et al. (1962) Showed that the flavor of chickens' diets can stimulate or depress feed intake. Aami-Azghadi et al. (2010) reported that cumin essential oil and Fermacto did not have a significant effect on performance parameters in the starter and finisher periods, but higher BWG was observed in birds fed diet with the lowest level of CEO supplementation in the grower period. At this experiment, pumpkin oil supplementation decreased mortality that can be related to pumpkin s' vitamin $\mathrm{C}$ content as a natural antioxidant and a reducer of heat stress.

Abdominal fat pad and carcass composition: At present study pumpkin oil supplementation decreased abdominal fat pad numerically, but it had not any significant effect on abdominal fat pad and carcass composition of broiler chickens. This is in agreement with the findings of Aami-Azghadi et al. (2010). They stated that supplementing 0.2, 0.4 and $0.8 \mathrm{~g} \mathrm{~kg}^{-1}$ Cumin Essential Oil to corn-soybean meal-based diets did not have significant effect on abdominal fat pad of the birds.

Blood parameters: Present study showed that pumpkin oil supplementation decreased the concentration of plasma cholesterol and triglyceride (Lee et al. 2003; Yasni et al., 1994). They found dietary Carvacrol (a component of Thyme essential oil) and "-curcumene (a portion of essential oil from Curcumaxanthorrhiza) lowered serum triglyceride. It has beenreported that dietary cumin seed or CEO lowered serum cholesterol concentration (Srinivasan and Sambaiah, 1991). The hypocholesterolemic effect of CEO has been ascribed to inhibition of 3-hydroxy-3-methylglutaryl coenzyme A (HMG-CoA) reductase (Srinivasan and Sambaiah,
1991), the rate controlling enzyme of the cholesterol synthetic pathway.

During the screening of a variety of plant sources for their anti-obesity activity, Choi et al. (2007) found that a water-soluble extract, named PG105, prepared from stem parts of Cucurbita moschata, contains potent anti-obesity activities in a high fat diet-induced obesity mouse model. In this animal model, increases in body weight and fat storage were suppressed by 8 -week oral administration of PG105 at $500 \mathrm{mg} \mathrm{kg}^{1}$, while the overall amount of food intake was not affected. Furthermore, PG105 protected the development of fatty liver and increased the hepatic b-oxidation activity. Results from blood analysis showed that the levels of triglyceride and cholesterol were significantly lowered by PG105 administration and also that the level of leptin was reduced, while that of adiponectin was increased.

\section{CONCLUSION}

In conclusion, supplementation diets with $5.00 \mathrm{~g}$ $\mathrm{kg}^{1} \mathrm{DM}$ pumpkin oil in corn-soybean meal-wheat based diet can be profitable because it reduced broiler chicken's mortality and it did not have any adverse effect on bird's performance. Also, pumpkin oil supplementation reduced blood fat of broiler chicken.

\section{REFERENCES}

Aami-Azghadi. M., A. Golian, H. Kermanshahi and M. Sedghi, 2010. Comparison of dietary supplementation with cumin essential oil and prebiotic fermacto on humoral immune response, blood metabolites and performance of broiler chickens. Global Veterinaria 4: 380-387. ISSN: 1992-6197

Alçiçek, A., M. Bozkurt and M. Çabuk, 2003. The effect of essential oil combination derived from selected herbs growing wild in Turkey on broiler performance. South African. J. Anim. Sci., 33: 8994. DOI: $10.3382 /$ ps.2009-00048

Al-Dabbas, M. M., Al-Ismail, K., Taleb, R. A. and S. Ibrahim, 2010. Acid-base buffering properties of five legumes and selected food in vitro. Am. J. Agric. Biol. Sci., 5: 154-160. DOI: 10.3844/ajabssp.2010.154.160

Botsoglou, N.A., P. Florou-Paner, E. Chiristaki, D.J. Fletouris and A.B. Spais, 2002. Effect of dietary oregano essential oil on performance of chickens and on iron-induced lipid oxidation of breast, thigh and abdominal fat tissue. Br. Poult. Sci., 43: 223230. DOI: $10.1080 / 00071660120121436$ 
Choi, H. H. Eo, K. Park, M. Jin and E.-J. Park, 2007. A water-soluble extract from Cucurbita moschata shows anti-obesity effects by controlling lipid metabolism in a high fat diet-induced obesity mouse model. Biochem. Biophy. Res. Commun., 4190425. DOI: 10.1016/J.BBRC.2007.05.107

Ciftci, M., T. Güler, B. Dalkiliç. and O.N. Ertas, 2005. The Effect of Anise Oil (Pimpinella anisum L.) On Broiler Performance. Int. J. Poult. Sci., 4: 851-855. DOI: $10.3923 /$ ijps.2005.851.855

Cowan, M.M., 1999. Plant products as antimicrobial agents. Clin. Microbiol. Rev., 12: 564-582. PMID: 10515903

Craig, W.J., 1999. Health-promoting properties of common herbs. Am. J. Clin. Nutr., 70: 491-499. PMID: 10479221

Deyoe, C. W., R.E. Davies, R. Krishnan, R. Khaund and J.R. Couch, 1962. Studies on the taste preference of the chick. Poult. Sci., 41: 781-784. DOI: 10.1016/0031-9384(85)90009-5

Ghaly, A.E., 2009. The black cutworm as a potential human food. Am. J. Biochem. Biotechnol., 5: 210220. DOI: 10.3844 /ajbbsp.2009.210.220

Gomez-Flores, A., P. Tamez-Guerra, R. TamezGuerra, C. Rodriguez-Padilla and E. MonrealCuevas et al., 2006. In vitro antibacterial and antifungal activities of Nopalea cochenillifera pad extracts. Am. J. Infect. Dis., 2: 1-8. DOI: 10.3844/ajidsp.2006.1.8

Gwanama, C., A.M. Botha and M.T. Labuschagne, 2001. Genetic effects and heterosis of flowering and fruit characteristics of tropical pumpkin. Plant Breed., 120: 271-272. DOI: 10.1046/j.14390523.2001.00595.x

Hernandez, F., J. Madrid, V. Garcia, J. Orengo and M.D. Megias, 2004. Influence of two plant extract on broiler performance, digestibility and digestive organ size. Poult. Sci., 83: 169-174. PMID: 14979566

Jamroz, D. and C. Kamel, 2002. Plant extracts enhance broiler performance. In non ruminant nutrition: Antimicrobial agents and plant extracts on immunity, health and performance. J. Anim. Sci., 80: 41. DOI: 10.3923/javaa.2009.2617.2620

Lee, K.W., H. Everts, H.J. Kappert, K.H. Yeom and A.C. Beynen, 2003. Dietary carvacrol lowers body weight gain but improves feed conversion in female broiler chickens. J. Appl. Poult. Res., 12: 394-399. DOI: $\quad 10.1590 /$ S1516635X2008000200006
Niu, J., Y.J. Liu, L.X. Tian, K.S. Mai and K.Q.C. Zhou et al., 2007. Maize oil can replace fish oil in the diet of grouper postlarvae (Epinephelus Coioides) without adversely affecting growth or fatty acid composition. Am. J. Agric. Biol. Sci., 2: 81-87. DOI: 10.3844/ajabssp.2007.81.87

Obi, R. K., F. C. Nwanebu, U. U. Ndubuisi. and N. M. Orji, 2009. Antibacterial qualities and phytochemical screening of the oils of Curcubita pepo and Brassica nigra. J. Med. Plant. Res., 3: 429-432. ISSN: 1996-0875. 20093319605

Ramakrishna, R. R., K. Platel and K. Srinivasan, 2003. In vitro influence of species and spice-active principles on digestive enzymes of rat pancreas and small intestine. Nahrung., 47: 408-412. DOI: 10.1002/food.200390091.

Salem, M.A., M. Zommara and K. Imaizumi, 2005. Dietary supplementation with Cyperus esculentus $\mathrm{L}$ (tiger nut) tubers attenuated atherosclerotic lesion in apolipoprotein $\mathrm{E}$ knockout mouse associated with inhibition of inflammatory cell responses. Am. J. Immunol., 1: 60-67. DOI: 10.3844/ajisp.2005.60.67

Srinivasan, K. and K. Sambaiah, 1991. The effect ofspices on cholesterol 7 alpha-hydroxylase activity and on serum and hepatic cholesterol levels in the rat. Intr. J. for Vit. and Nutr. Res., 61: 364369. PMID: 1806542

Valero, M. and M.C. Salmeron, 2003. Antibacterial activity of 11 essential oils against Bacillus cereus in tyndallized carrot broth. Int. J. Food Microbiol., 85: 73-81. DOI: 10.1016/S0168-1605(02)00484-1

Yasni, S., K. Imaizumi, K. Sin, M. Sugano, G. Nonaka and S. Sidik, 1994. Identification of an active principlein essential oils and hexane-soluble fraction of Curcuma xanthorrhiza Roxb. Showing triglyceridelowering action in rats. Food Chem. Toxicol., 32: 273-278. DOI: 10.1016/02786915(94)90200-3

Yazdani Moghaddam, F., J. Darvish., N. M. Shahri., A. S. Abdulamir and S. K. Daud, 2009. Lectin histochemistry assay in colon tissues for interspecies characterization. Am. J. Biochem. Biotechnol., $\quad$ 5: $\quad 7-13 . \quad$ DOI: 10.3844/ajbbsp.2009.7.13

Yu, P., 2007. Protein molecular structures, protein subfractions and protein availability affected by heat processing: A review. Am. J. Biochem. Biotechnol., $\quad 3: \quad 66-86 . \quad$ DOI: 10.3844/ajbbsp.2007.66.86 